JAKUB NIEDBALSKI (1)

University of Lodz

\title{
BETWEEN (SELF-)EXCLUSION AND SOCIAL INTEGRATION - ANALYSING THE PROCESS OF RECONSTRUCTING IDENTITY OF PARENTS OVER THE LIFE STAGES OF A CHILD WITH INTELLECTUAL DISABILITY
}

\begin{abstract}
The paper is devoted to creating and articulating the identity of parents of children with intellectual disability. In this work, I have sought to deconstruct identity reconstruction in parents of children with intellectual disability and learn about the ways these parents perceive the world around them, making sense of certain elements, which in turn provides a basis for them to take action to shape their living space. Therefore, to embed the analysis in a broader theoretical perspective, I refer to the crucial assumptions of research on social life that derive from the theory of symbolic interactionism. The research material came from interviews about the parents' personal experiences. The data were analysed according to the grounded methodology principles.
\end{abstract}

Keywords: disability, family, child, identity, qualitative research

\section{INTRODUCTION}

The socialization and upbringing processes that take place in a family allow the parents of a properly developing child to look at this young person gradually become independent and prepared for self-sustenance. Thus, the parents can enjoy their child's growth as it undergoes internal changes that, eventually, lead

Dr hab. prof. UŁ, Faculty of Economics and Sociology, Institute of Sociology; e-mail: jakub.niedbalski@uni.lodz.pl; https://orcid.org/0000-0002-2803-7628 
to maturity. This proves crucial since parenthood, although believed to be one of the tenets of a fulfilled life in individuals, is accompanied by numerous hardships, reliability issues, and challenges. In this regard, the changes, progress, and development of a child should come as a result of the efforts of parenthood.

It proves different in the case of people with intellectual disability, in particular, those with a significantly lower intelligence quotient because it is difficult to achieve the same psychosocial development level that would provide a basis for autonomous or independent living in social relationships. This, in turn, means that the expectations and requirements for people with intellectual dysfunctions must be different as well. Parents cannot enjoy the independence of their intellectually disabled children, their progress, or the transformations that lead to maturity. Despite the great effort, involvement, and the need to overcome difficulties that occur at almost every step, parents of children with intellectual disability (especially severe disability) do not usually have the opportunity to observe their development as is the case with families of fully capable children. Furthermore, long before the child reaches adulthood, the parents usually know that their offspring will never be fully independent and self-reliant.

The arrival of a child with a disability redetermines the inner life of a family, reshaping the duties, functions, and tasks assigned to each member and destroying the previous organizational order. The presence of a person with intellectual disability in a family creates a unique and challenging situation for that family system. As a result of experiencing an increasing number of challenges in family life, which often exceed the possibilities and mental resilience of the family members, particular people, especially the parents, encounter a role crisis and identity disintegration. For families with a child with an intellectual disability, excessive upbringing efforts and poor outcomes often lead to burnout syndrome.

Taking the above into consideration, the phenomenon of disability can be seen as a social construct that - taking on an embodied character - becomes a source of stigma for parents with disabled children. For this reason, the main focus of the article is the process of reconstructing the identity and redefining the situation of a parent of a child with intellectual disabilities, as captured in their individual personal experiences, accessed through in-depth interviews.

\section{BACKGROUND}

The research on families with a child with intellectual disability shows that the situation of a family system is not only difficult but also unique. The emergence of a disability in a child determines the life within the family, giving each mem- 
ber new responsibilities, functions, and tasks, and often destroying the former order [see Phyllis, Draine 1995; Hodapp, Glidden, Kaiser 2005], among others. When a child has an intellectual disability, the family's functions are most often distorted, and performing vital roles requires a serious amount of work, which involves a great deal of psychological stress for the members [Hodapp 2007; Phyllis, Draine 1995].

Parental identity is related to experiencing oneself as a parent. In this sense, parental identity is a reflection of the subjective evaluation of oneself in the role of mother or father. One of the most important skills for a parent raising a child with an intellectual disability is to redefine the role of father/mother and reconcile conflicting concepts about parenting. Research has suggested that parents' aspirations were focused on, among other things, achieving a balance between parenting and caring roles, maintaining their personal identity through work, interests, and personal relationships, and maintaining family life, including their relationship with their spouse [Beresford, Rabiee, Sloper 2007]. Caring has been described as identity-defining in the way it changes the carer's life [Holland, Blood 2008], and some parents have described losing parts of their identity, with the parent-carer dominating, and identified redeveloping aspects of their identity as a personal aspiration [Beresford et al. 2007]. The parenting role has been identified as potentially overwhelming other aspects of self-identity, even to the point of becoming an overwhelming, or even the sole source, of self-meaning [Todd, Shearn 1996a].

It is also of note that much of the literature conflates the parent and carer roles in particular, rather than treating these as separate self-identities with separate implications. However, studies with carers in various relationships with care recipients have identified multiple and often simultaneous identities, which may be implicitly or explicitly designated separately from that of carer, including spouse, parent, friend, or individual person [e.g., Holland, Blood 2008; Hughes, Locock, Ziebland 2013; Todd, Shearn 1996a].

Importantly, a number of studies have suggested that identity is shaped for parents over time, through the experiences and transitions of their roles. For example, the formation of the parental identity - and aspirations for future identity - are challenged and influenced by the diagnosis of an impairment [Rix, Paige-Smith 2008; Bosteels, Van Hove, Vandenbroeck 2012]. However, transitions, both physical and emotional, continue to occur throughout time [Ytterhus, Wendelborg, Lundeby 2008]. These transitions occur for all families; however, for parents of children with disability, they are experienced differently, often representing greater physical and emotional challenges than those experienced 
by other families [Ytterhus et al. 2008]. At certain turning points, such as their child's adolescence and adulthood, the normalizing strategies used by parents are no longer as successful, with the particular challenges of their family situation brought into stronger focus and challenging parents' self-identity [Todd, Shearn 1996a].

The ongoing revisions of identity that occur through these transitions over time highlight the struggle between the expression of multiple self-identities [Todd, Shearn 1996a]. Broader identity theory recognizes the shifting nature of identities and the potential for two or more identities to exist simultaneously; when they are in opposition, it may result in dissonance and shifts in or changes in the relative salience of the identities, and the individual withdraws from the associated relationships [Burke 2003]. Todd and Shearn's [1996b] research differentiated between 'captive' and 'captivated' parents; that is, parents who experienced parenting as restrictive and desired the lifestyle of their peers, and those who gave up their personal aspirations and ambition to achieve their peers' lifestyle, finding a positive meaning in their role as parents. Walden, Pistrang, and Joyce [2000] further suggested that this may be a continuum, although they also emphasized the contrast and the struggles between these identities.

Studies show that one of the effects of a child's intellectual disability may be the underestimated self-esteem of the parents. The sense of value experienced by parents is often lost in individuals raising mentally impaired children, which, in turn, leads to social exclusion [cf. Orsmond, Seltzer, Krauss, Hong 2003]. This happens because society avoids contact with disabled people and their families as it fears their otherness, possible issues, and the manifested behaviours that are sometimes considered unusual because they are incomprehensible [cf. Barnes, Mercer 1997]. The research conducted by Gray [2002] among parents of children with disabilities shows that it is characteristic for most of them to experience a stigma in the form of feelings of shame. To a lesser extent, there is stigmatization perceived in the form of avoidance, hostile stares, and rude comments. On the other hand, Stengler-Wenzke et al. [2004] conducted a study on stigma transferred onto relatives of people with mental disorders, which revealed that their share of negative behaviours was manifested in being advised of the need to hide the disease, in rejection, blaming, or even insults.

This paper focuses on the experiences of parents of people with disabilities, directing attention to the process of reconstructing identities and redefining situations of the subjects given the key stages in their children's life stages. Thus, the paper is devoted to issues that have not been sufficiently articulated in the literature. In this study, the parents of children with disabilities talked about how 
their parenting experience shaped their identity, and it was often the most important challenge in their lives. Consequently, this study sought to deconstruct the processual nature of identity construction of parents of children with intellectual disabilities and to explore the ways in which these parents perceive the world around them and how they experience their own parenting. These findings are vital for understanding the situation of the subjects as mothers and fathers of children with intellectual disabilities considering key elements that influence their identity.

\section{MATERIALS AND METHODS}

The research material adopted in this study is the data obtained from non-structured interviews with parents who had experienced significant transformations in their lives related to bringing up and taking care of their disabled children. This type of data acquisition tool meant that each of the interviews was individualized. The course of each interview was moderated on an ongoing basis, and its content depended primarily on what issues were pointed out by the interviewees and how they emphasized the information that arose during the interview.

At this stage of the research, 40 reviews were carried out between 2017 and 2019 among the parents of children with intellectual disability. The interviews were performed with 26 women and 14 men between 36 and 78 years old, and they usually lasted from 1 to 3 hours. Before analysis, the interviews were transcribed verbatim, preserving the details of the interviewees' utterances as faithfully as possible.

Data collection and analysis procedures were informed by Charmaz's [2006] account of grounded theory. The aim was to gain a rich and in-depth understanding of the experience of parents parenting their son or daughter with intellectual disabilities, taking into account the multiple perspectives and circumstances of the parents. As grounded theory acknowledges the existence of multiple socially constructed realities, this approach is well suited to the study.

In keeping with grounded theory, an inductive approach to analysis was used to develop categories and themes from the data, rather than trying to fit data into prescribed categories. Two stages of coding were used in Charmaz's [2006] grounded theory: (1) initial coding, which involved analyzing the data to search for the participant's meaning, and (2) focused coding, when the most useful or pertinent codes were selected to represent the themes that were emerging from the data. The researcher moved between stages of coding and between transcripts to compare the codes and themes that had been identified. In keeping with 
Charmaz's account of grounded theory analysis, a core category was developed to explain the phenomenon.

The selection of subsequent cases for the research was of theoretical sampling and based on the constant comparative method. Thanks to theoretical sampling, while collecting, encoding, and analyzing the materials, the researcher makes simultaneous decisions about where and what data to collect [Glaser 1978, Strauss, Corbin 1990]. While applying the constant comparative method in the search for other data, were tried to choose cases that are both highly varied and similar to each other to grasp the maximum number of conditions that differentiate the presence of categories and their mutual correlations [Charmaz 2006]. Data collection and analysis in constructivist grounded theory are usually stopped once saturation is reached. Saturation was not reached in all themes due to the aforementioned issues with recruitment, but it was achieved for most themes in the theoretical framework. NVivo 12 [Miles, Huberman, Saldaña 2014; Niedbalski, Ślęzak 2012] was used to organize the codes and themes.

\section{RESULTS}

Following data analysis, three key stages were identified in the life of a person with disability: childhood, adolescence, and adulthood. They occur within the span of successive psycho-physical changes that occur in a child, and in turn, they are accompanied by transformations in the parents' identity. In adulthood, I also added the category of "old age vision" because parents of people with disabilities begin to experience old age when their children reach full adulthood. Thus, the narratives of these parents often include the theme of "what will happen later", i.e., when the care they provide cannot be continued (due to a loss of strength as a result of illness or old age, and, finally, death).

\section{Acquiring an identity as a parent of a child with intellectual disability}

The turning point that marks the onset of the period of reconstructing the parents' identity is usually when they learn that their child has an intellectual disability (it is often just a suspicion that the son or daughter may have a disfunction). The timing of the "appearance" of the disability in the parents' (and more broadly, the whole family's) lives may differ vastly, and it can refer to pregnancy (which often happens nowadays in the era of prenatal examinations) but also to perinatal circumstances or various complications accompanying neonatal and early childhood diseases. However, regardless of when this moment that is crucial for 
them and their child is situated on their timeline, it is always unwanted and brings a whole range of challenging experiences and negative emotions.

It is also often the case that this information lacks a clear and definitive qualifying dimension. The peculiarity of this situation is that, at first, the "diagnosis" may only be an assumption, and only after some time does it become a fact. It is a state of disorder that does not allow for a stable living situation. Parents function between what can be described as reassuring thinking, that everything is fine, and an irresistible conviction that something bad is happening.

As I reproduce in my mind these moments that are difficult for me and our whole family, I must admit that I kind of ran amok at that time. I can't remember exactly how it was because everything blurs into one image. But it was a time when everything went haywire, went sour, but mostly it was a balancing act between what the doctors said or didn't want to say right away, and what was becoming more and more apparent and harder and harder to deny. $[i .17 .17]^{1}$

The news that a child is (or may be) intellectually disabled leads to a situation in which the parents experience an unexpected yet extremely strong mental and emotional shock. Using the nomenclature adopted by Riemann and Schütze [1992, 1997], the described events can be determined as an accumulation of trajectory potential, i.e., having certain biographically conditioned dispositions to be hurt. In the case of parents of intellectually disabled children, their expectations of the child (especially an unborn one) and their parenthood may account for this potential, and thus announce the future trajectory [Rieman, Schütze 1992: 104]. The gathering of the trajectory potential is accumulative and does not stop at the diagnosis, which is often rather a presumption rather than a fact [Niedbalski 2019].

This uncertainty accompanied us at that time, this sense of a lack of clarity of the situation, and the constant questioning of ourselves, what next, what now, what will happen tomorrow? I don't even know what I was thinking at the time anymore, because I think I had one big chaos in my head and a feeling that the ground was slipping away from under my feet. They were terrible moments that dragged on forever. [i.19.09]

This event causes a breakdown in expectations of the normal (and therefore known) course of future events related to the upbringing, development, and adolescence of a healthy child. According to Riemann and Schütze's [1992] trajectory theoretical framework, there is then a crossing of the boundary between intentional and conditioned mental states, and the affected person cannot shape

1 I use indications of the quoted fragments of my respondents' statements throughout the article, where the letter " $\mathrm{i}$ " means an interview, the first figure indicates the year when the interview was carried out, and the last figure is the number of the interview. 
their daily life through active action patterns. At that point, the parent of a child with a disability realizes that they can no longer live according to familiar patterns, causing a growing sense of confusion, loneliness, and abandonment [Niedbalski 2019]. This is because various aspects of the parents' lives are transformed with the arrival of this child. First and foremost, this applies to their immediate circle. The family of a disabled child has to face a kind of social ostracism because of the child's special needs.

\begin{abstract}
Yes, we can try to arrange a meeting with our friends to go out for ice cream or to the park on Sunday. And we might even be able to get there. Sure, friends are happy to stop by a few times to have coffee and talk. They may even be willing to take care of our healthy little one from time to time and take her to the park to play with their poppets. But other common activities outside our home are under a big question mark. Healthy children often do not want to play with sick children because they do not understand their different behaviour. Adults also lose the urge to keep in touch after a while - because how many times can you accept cancelling another appointment because your child's health has deteriorated? [i.18.09]
\end{abstract}

This is also because parents of children with disabilities differ from parents of healthy children, and not only in terms of everyday problems or time management opportunities. Among other things, the atmosphere in which meetings take place is of great importance, i.e., whether the child's parents can psychologically "isolate" themselves from their problems and whether other people can show sufficient empathy and patience. Among those who do not have direct contact with disability, there may be a reluctance to listen to sad stories about the daily worries of a family with a disabled child, which sound abstract and surreal, even to a mother of several healthy children who has encountered a wide range of experiences and has already dealt with several difficult life situations. Thus, it is not uncommon to conclude that such an acquaintance does not bring joy but stress to those around as well as to the parents of the child with a disability themselves.

Who enjoys hearing tales of woe that don't end like a Sisyphean task! How many times can you listen to an incomprehensible story about fighting an epileptic seizure or another upper respiratory infection? [i.18.03]

Another respondent had a similar point of view, pointing out the difficulty that parents of fully capable children have communicating with those of disabled children, even if the former show an interest and try to maintain interpersonal relationships with caregivers of disabled children. However, this interest and willingness to maintain contact weaken over time as the gap between the lives of one parent and the other becomes more apparent. The extent and nature of the differences separating the caregivers of children with and without disabilities are 
so significant that, over time, the strength of the relationship decreases, eventually reaching the point where contact is severed.

It's obvious that we look for people with whom we find common topics. So in the beginning, when we meet new people, we exchange information about ourselves. Others show a polite interest in your family, and when they learn of your child's illness, they gently ask what is going on and try to understand. But over time, someone has had enough... And so sooner or later, the "healthy" friends start to disappear from our horizon. And that breeds frustration, loneliness, and a lack of acceptance. [i.17.05]

At the same time, it is extremely difficult to make new friends, and the social space for making contacts with other people is very narrow and usually limited to those who are in a similar situation, which is evident from where and in what places parents of a child with a disability hang out. When the child's condition is stable enough to participate in rehabilitative, educational activities outside the home, it gives the caregiver a more frequent opportunity to get out to the outside world and to meet other parents who may be struggling with similar issues. And thus, it provides a break from everyday life and an opportunity to make friends. However, when a child is medically unstable, recumbent, care is usually based on a team of visiting specialists. However, it has the downside that by not leaving home for therapy classes, parents lose the opportunity to meet others, and this intensifies the caregiver's alienation and the sense of loneliness in the fight against the disease.

I am constantly fighting to make my child more capable, so that he can do more on his own, without the help of others, to make him as independent as possible. That's why I do everything I can. First of all, I use the help from people, that is, rehabilitation specialists and therapists who come to our home. This makes things easier, as Harry ${ }^{2}$ is practically immobile, and taking his wheelchair from the third floor is simply a nightmare (...). The only thing I miss about this situation is that I practically don't leave my home and sit in one place constantly. [i.19.03]

Another element that shapes parenting of a child with limited mental capacity is the conflict between parental responsibility for the offspring and realizing plans, dreams, and needs [cf. Kościelska 1995]. As suggested by the interviewees' statements, caring for a disabled child may force parents to give up their ambitions, interests, or professional work, which in turn threatens their self-fulfilment. In such a situation, it is difficult to find solutions that parents would consider both effective and morally appropriate. Prioritizing the child leads to social isolation, suffering, a sense of meaninglessness, and lowered self-esteem. In contrast,

2 All children's names were changed throughout the article. 
pursuing personal plans can create guilt and expose the parent to negative judgment from those around them. In this way, the intellectual disability of the child, or rather, its individual and social consequences - in the form of tension and conflict of roles - constitute a threat to the mother or father's parental identity.

After Peter was born, I didn't return to work. It just wasn't an option because he had to be cared for 24 hours a day. Of course, this is true for every child when they are young, but Peter, even now that he is 18 , still needs constant care. And I'm at home with him, and my husband works. All in all, it would have been difficult to do otherwise, but nevertheless, it started to tire me a bit sometimes that I couldn't just go out, that I had to watch him all the time, whereas my friends had the opportunity to go out, to talk to someone and they could be active, they could work, and I didn't. [i.18.8]

For parents of children with disabilities, the conflict of roles often arises at work, because at least one of the parents (usually the mother) must devote themselves to caring for their son or daughter, which in practice makes it impossible for them to take up or continue working. In most cases, the diagnosis of a child's terminal illness involves one parent having to give up their job to provide 24-hour care for the child. The natural consequence, of course, is the loss of salary, and thus the family's financial situation deteriorates. The family has to mentally and emotionally deal with both an illness and a drastic increase in expenses for daily care products, expensive equipment, and rehabilitation treatments.

However, depending on the severity of the disability or the stability of the patient's condition, sometimes, after sorting out the situation and working out some compromises, the caregiver can return to work outside the home. Such people are considered lucky because they have managed to find a replacement to provide the necessary care. At the same time, they have a job that not only supports the household finances but also integrates them socially, which undoubtedly has a better impact on their well-being and self-esteem.

I go to work to rest from my child's illness so that when I get home, I can deal with it more effectively and confidently. It's a kind of refuge for me, from what awaits me at home. In my opinion, the real work that parents of people with disabilities have to face is not the professional job, but that at home with their child. [i.18.02]

Another difficulty that parents of a child with a disability have to deal with, and which affects their self-definition, is the range of social prejudices against people with different kinds of dysfunctions. Despite the passage of years and the changes that have taken place in this area, leading to the gradual "disenchantment" of disability, several negative associations and stereotypes that stigmatize people with disabilities and their families still function in society. This often causes parents to alienate themselves from their surroundings, avoid interacting with 
other people, and feel unsafe in any new situation or unfamiliar place. In this way, they try to protect not only their child but also themselves from stressful and distressing events that can strongly impinge on their sense of psychological well-being, ultimately contributing to devaluing their self-esteem and putting themselves in the role of accepting the stigma of disability.

Unfortunately, our society, whatever one may say, is backward, and there is still much to be done and changed. I'm not talking about everyone because it wouldn't be true, but there are quite a few people who don't understand disability and perceive those with disabilities as lepers. It's like you can get infected with it. And that's why I have such resistance and reluctance to just go out like that. After all, the whole expedition is extremely stressful for me because you never know what can happen on the way, and when I additionally can have the impression that people are looking at me and treating me like some kind of freak, it just makes me want to stop doing everything. [i.19.07]

Despite the circumstances of everyday life described so far, which are not always favourable and that involve progressive isolation and exclusion, many parents of children with disabilities go through a process that can be described in terms of the already mentioned trajectory (suffering), reaching a point where they can achieve a relative, albeit shaky, balance in their lives. However, this is not the end of the family's struggle (including with psychosocial problems), because with time, as the child grows and psycho-physical changes connected with this progress arise, new problems appear and the scale of difficulties in various spheres of life turns out to be greater than during childhood. All of this exerts an impact on the parents who not only have to deal with all sorts of nuisances and familiar difficulties on a daily basis but also further challenges brought on by their child's disability.

\section{Reconstructing parents' identities in the adolescence of their children with disabilities}

As one of the stages of human development, adolescence is characterized as a transitional stage between childhood and adulthood. It is the period when the problems of psychosexual and psychosocial maturation are concentrated. It is often the case that in the middle of these breakthrough events, when the parents feel that they have discovered new potential to act, they are burdened with the upcoming changes related to the beginning of their child's adolescence. It is stressed in the following statement.

Yes, well, unfortunately, when we thought we were past the worst, and that it would be just better, it turned out that we were just entering the time of real disappointment, because even though we managed to do a lot and let's say we were out of the woods with Harry, there came 
the deadlock at the beginning of adolescence, and gradually, instead of improvement, there was deterioration, going back to the previous state. So, my wife and I realized that we can't do more or that it might get even worse, which worried us, because we thought about the future right away. [i.18.02]

When a child enters adolescence, there is not only the need to reconstruct the organization of life, but there are also new problems that the parents have not encountered before. Therefore, there is the need to update previous and developed formulas of coping with everyday life as a parent of a child with a disability. The endless repetition of procedures accompanied by accumulating new responsibilities and interaction problems. The frequent tensions between parents in this respect means that adolescence is not only a time of other disappointments, but it also invites the feeling of hopelessness and anguish in family members. It is increasingly difficult for the parents to carry out particular actions involving the child as it gets older and the advancing physiological changes.

At the same time, the changes in appearance and behaviour of an adolescent child with a disability are not only a source of suffering for the parents but also a threat to the course and maintenance of further interactions with their immediate surroundings. Bodily changes often lead to the reconstruction of how an adolescent child with a disability is perceived, and it so happens that such children can directly elicit reluctance or even disgust. During childhood, especially in infancy, a disabled child may not be significantly different from its fully capable peers. And even when differences in appearance are noticeable, a young child with a disability is still better received than an adult or an older person. Society accepts such a child much more easily and produces less intense responses to its disability, which has a direct influence on the links between the parents and the "outside world" (external to the family).

Unfortunately, when George grew up, he no longer fitted in a regular baby stroller, and we needed to carry him in a different, special stroller. And then it wasn't possible anymore to hide that that he is not a normal child, because the stroller itself aroused some interest. But it was even worse that George's appearance changed, and he turned from a child that looked almost normal into a teenager and then an adult who looked like an ill person. [i.18.02]

The new condition arising from adolescence may cause people to be more reluctant to have any contact with the disabled individual and, as a result, with their parents. It is not only strangers but even family who avoid serious conversations with the parents, who are uncomfortable, and who become not only emotionally but also mentally distant. The reasons for this should be sought for in the sociocultural perception of a body considered to be normative. Changes in the appearance of an adolescent child with a disability are a clear contradiction 
of this normativity, which makes them a difficult barrier to overcome for many, both in their perception of disability but also through direct contact with a person who has visible and unconcealed dysfunctions.

The parents' response to what happens with a child is often a rebellion caused by powerlessness and the awareness that the situation will not change. At the same time, they understand that what has happened to them is permanent and irreversible, and both their lives and the life of their disabled child will be permanently "burdened" with a load of "otherness" and imperfection. It is also significant that parents have already gone through a host of experiences (many more than during the first years of the child's life), and they have already worked through what had happened to them concerning the birth of their disabled son or daughter. Therefore, the rebellion more often gives way to rationalization attempts, which means searching for alternative solutions and sources of joy and life satisfaction. New attempts are made to explain the reasons for their suffering and to morally assess what is happening. Redefining their situation including analysing the influence exerted by the process of suffering on the previous, present, and future modes of life - both theirs and their child's.

It is as it is. I can't do anything about it. I can only do what's important for me and my child, and that makes me see the sense and even some kind of joy in it, because every gesture, every grimace or movement of the head, is a lot for me, and it makes me happy when I see the satisfaction in the eyes of my child. I don't know who I'd be without my child, what my life would look like, but I can't imagine this life without him, without what we have experienced together. All of this is a part of me, and without him, I wouldn't be the person I am now. [i.17.02]

The parents try to explain to themselves that they cannot do anything about their child's disability as time passes; they can only provide it with the best living conditions possible. At the same time, they are unable to prevent the numerous adverse changes that take place when a son or a daughter reaches a certain age. However, they must consider that, over the years, there are no visible effects in the form of their child gradually becoming independent. The parents start to focus more on the present, gradually shifting their activity from forms of rehabilitation, which was previously intended to achieve the possibly highest level of development, to supporting the child to maintain the achieved level and support the child's independence. However, when it turns out that despite numerous actions and involvement of the parents in their child's improvement process, the condition of their child in adolescence and, afterward, in adulthood, is marked with regression, the parents focus on providing the greatest life quality possible, putting the main emphasis on care and nursing procedures. 
As I have already mentioned, I'm not counting on a miracle because it won't happen. But I also have nothing to reproach myself for, because I did everything I could to make my child as independent as possible. It might be too big a word because Dominica needs constant care, but she doesn't lie down all the time, she can move in her way, so this is my success. And now I want to keep it at all costs and not make it worse. I want her to have the best care, rehabilitation, simply a dignified life. [i.18.09]

The period of adolescence is a time when, on the one hand, new problems emerge but, on the other hand, those that seemed to have been solved return, although in a changed form. Therefore, after a period of relative stability during childhood and the associated development of specific rules for raising a child, there is a period of dynamic change resulting from adolescence. This is when the parents must not only take on the hardships of everyday life so far but also face the further demands of their child entering adulthood.

\section{Reconstructing parents' identities in the context of the "adulthood" of their intellectually disabled children}

As the parents get older, their performance decreases, and in the case of children with intellectual disabilities, psycho-physical problems very often increase with the transition to the next developmental stages. On the other hand, parents have cooled down over the years and have gained some distance from their own and their child's life situation. As a result, they tend to have much lower aspirations for their adolescent son or daughter concerning, among other things, becoming independent (how they perceive the child's independence and what they mean by this concept largely depend on the child's objective predispositions but also the subjective expectations of the parents). Nonetheless, the idea that the child will be inextricably bound to the parent for as long as the parents are alive and thus cannot expect help or support from the parents once they grow old, can cause feelings of hurt, disappointment, and sometimes anger. Therefore, parents try to find all those behaviors and situations their child participates in that are indicative of their child's developmental progress or at least provide a counterbalance to their child's often deteriorating condition as they get older. In this way, parents seek confirmation (often of a wishful nature) that their child, despite their dysfunction, can achieve a certain level of independence and thus, at least to a minimum extent, follow the developmental path of healthy children.

For me, now, it's most important that Maddie has the best possible living conditions. I know I won't change how she is, and I can't do anything else to heal her. I can just give her a sense of comfort, peace, and the best life possible despite the various unfavorable conditions and many barriers or limitations we need to face together. [i.17.05] 
Parents desire self-sufficiency for their child, and hope they will do well at school and have a successful career in the future. However, a child with special needs is not only a threat to those dreams, but these two aspects often rule each other out. It is worth noting in this context that adulthood is not only a metric fact but, first and foremost, a process related to achieving subsequent stages of maturity. It is composed of biological maturity (the end of growth processes and the ability to procreate), social maturity (e.g., the ability to live independently), and emotional-moral maturity. Maturity can also be seen in the acceptance of oneself and one's limitations. It is also a period of undertaking family, social, and professional roles. Unfortunately, also in this aspect of life, the parents of an intellectually disabled child usually must come to terms with the fact that their son or daughter will never become a mother or father - they will never start a family or have a fully independent life.

I'd want that, really, but I know that it's completely unreal. I know not only that I will always be a mother of a child that will never grow up, but also that my child will never be a parent. And because this is my only child, I will never taste what it's like to be a grandmother, because I'll never see my grandchildren. [i.18.06]

Performing the simplest activities of daily living proves to be a growing problem. People with disabilities, especially those who have problems with mobility (or a very static lifestyle), often gain weight, and it becomes simply impossible to "handle" them without specialized equipment or third-party assistance. At the same time, there is a slow decline in the parents' abilities, which makes it aggravatingly difficult for them to give them the necessary care and maintenance as they age. At that time, thoughts about the child's future after they die or when they are unable to care for them due to illness, etc., also take up more and more space. As the child reaches adulthood, parental concern about the child's quality of life emerges. According to Sałkowska [2015: 91], "parents at the beginning of their parenthood, i.e., when their child is still small, fear that it will experience a significantly reduced quality of life, because this is how they would feel in the place of the child, not being able to benefit from all the intellectual opportunities or entertainment." These concerns grow with time when a child matures, becomes an adult (in a physical sense), and the parents gradually start to feel not only the problems related to their aging but that also result from physical changes in their son or daughter, largely related to greater weight but also retention or even regression in the development of their child that accompanies adolescence. 
Tom is like my beloved cat, this is how I refer to him caressingly because he fawns all over me, but sometimes he can also show a claw (laughter - note by JN). A big cat, as you can see, because he's already an adult man. He's an adult and I'm becoming old. This is where I see the problem for the future. He will be bigger with time, and I, well, nobody will give me additional strength, and time is unfortunately passing. [i.18.03]

The parents' concern is not only with care but also understanding the child's needs and maintaining and providing the child with an adequate sphere of sensitivity, feelings, and emotions. Parents usually try to express and confirm their full and unconditional acceptance of the ill, in the condition they are in, with every gesture and action. Thus, the parents are distraught that their child will be treated as an object, deprived of the dignity and subjectivity that the parent struggled to achieve, maintain, and express with their actions.

Who better than me will be able to understand Harry? I've been with him for years and I know his every gesture, every move, every grimace on his face. We have this language of ours here, a way of communicating. And you need to have the patience of a saint with him. This is why I don't know if anyone else would be able not only to devote as much time as he needs but even to try to understand him. [i.18.05]

The future of a disabled child is both problematic and painful for parents. There are doubts and a question: what will happen to my child after my death? The more a child depends on carers, the more difficult the question becomes. The awareness of putting a child in a place that fails to guarantee development and support is often painful for the parents. Only a small group of the interviewees had thought this issue through and were capable of verbalizing their intentions. Their statements indicate that they usually did not see a good solution to this problem. Rather, they showed bitterness about the poor quality of services offered by nursing homes. They experienced a distinct lack of support from the family and institutions. Some of the interviewees directly expressed the belief that it would be best if their disabled child died together with or shortly after them [cf. Konieczna 2012: 279; see Tomczyszyn 2015: 59].

I can't imagine what might happen to Maddie when she's left alone. I say alone because I don't want to get my other kids involved in this. They have the right to their own lives. They must remember about their sister, but I can't expect them to give up their own lives for her. It's enough that I had to do it. But on the other hand, I can't imagine Maddie going to an institution. Nobody will give her the help she receives from us, at home. I prefer not to think about it because it simply terrifies me. [i.17.04]

Old age is usually associated with a vision in which parents can enjoy their children's growth and maturity while, at the same time, feeling genuinely supported when they can rely on their child to help them because of their age and 
accompanying infirmities. One of the greatest joys for a parent is the independent and happy life of their children, who, while pursuing their plans and dreams, do not forget about their mother and father. However, for parents of people with intellectual disabilities, such a vision is very often difficult or even impossible to achieve. They realize from the very first years of their children's lives that both their lives and the lives of their son or daughter will not be "standard"; in fact, they are usually far outside the mainstream of parenting. The awareness of such a situation, as well as all its consequences in life, is a difficult challenge that parents have to face almost at every step, every day, overcoming numerous adversities, often feeling the burden of their children's non-normativity.

\section{DISCUSSION AND CONCLUSION}

As research has shown, the parenting experiences that shape the sense of maternal and paternal identity, and that relate to the constructing the role of father or mother, are inextricably linked to the meaning that the parent and society give to the relationship with the child. Difficulties may result not so much from the disability of the child itself but from not being prepared for the role of a father/ mother of a child with a particular dysfunction [cf. Singh 2019], or from social labeling [cf. Pavia, Mason 2012].

Most parents of intellectually disabled children during their childhood and adolescence had no contact with adults who were in parental roles with a child with limited intellectual ability. Thus, they did not have the opportunity to "learn" what it means to be a mother or father of a child with a disability. The child's intellectual disability represents a contradiction to the previously internalized, developed, and "standardized" scenario of everyday life practices. Therefore, opportunities for such parents to plan their own activities tend to be compromised. Similar conclusions were reached by Singh [2019: 838], who stated that parents of a child with a disability often live from day to day with limited ability to anticipate and plan for the future. Meanwhile, Ryan and Runswick-Cole [2008] noted that, for the most part, parents of children with disabilities do not have any prepared and internalized parenting patterns and therefore have to do the extra work of reconstructing a "new" parenting identity.

Stepping into the role of a parent of a child with a disability makes it necessary to do difficult and emotionally taxing identity work, going through a process of reconstructing their concept of self within the various social contexts in which they function on a daily basis. In some cases, tension was evident between the parents' positions in their talks about planning. At times, this tension was explicit - such 
as in a discussion about balancing their child's needs with their own, or balancing their child's needs with other family relationships, including spousal and parental relationships. This resonates with previous studies that found that in caregiving more generally, tensions arise between positions, such as between those of spouse and carer for people who care for a spouse [Hughes, Locock, Ziebland 2013], or between person or 'human being' and carer [Holland, Blood 2008]. Meanwhile, simply being a person with their own needs can become a source of guilt [O'Connor 2007; Todd, Shearn 1996a; Ytterhus, Wendelborg, Lundeby 2008]. Todd and Shearn [1996a, 1996b] highlighted the tension between the expression of different identities, particularly the struggle to realize an aspirational identity beyond that of parent or carer.

Since there are no behavioral patterns in the society that can be an indicator in raising a child with a disability, the process of adapting to the role of parenting such a child requires that many previously unknown difficulties be overcome. This journey of "becoming" a parent of a person with a disability occurs within a network of social relationships and existing limitations that the individual encounters and appropriately adapts to, tames, and within which he or she takes various actions. In the subsequent stages of following this path, the individual is put through various tests, some of which end in failure. At the same time, as this research shows, and as Singh [2019] also confirmed, they are embedded in the life trajectory of parents of children with intellectual disabilities. On the other hand, there is no shortage of positive resolutions to the subsequent trials faced by such parents. How they deal with and how smoothly they manage to function in different contexts of everyday life is strongly related to the socio-cultural capital they possess. This corresponds with the findings of Singh [2019], according to whom educational level, socioeconomic status, race, and ethnicity all play a role in how well a parent of a child with a disability is effectively able to navigate the boundaries associated with raising such a child. This is also indicated by Ryan and Runswick-Cole [2008], who argue that a child's success depends on its parents' proficiency in medical terminology, educational law, insurance policies, and all kinds of institutional procedures. Their findings also demonstrate that for many parents, their perceptions of parenting or prior parenting experiences in the context of a typically developing child is a poor reference point. They are required to reconstruct a 'new parents' identity', which is shaped by socio-cultural factors.

The socio-cultural context also has implications at the gender level, as it is the mother of a child with disabilities, rather than the father, who is often put in a position where they are expected to take on an unconditional and more selfless 
role as the child's caregiver. This corresponds with Cronin [2018], who states that there is a sense that mothers have a "special identity" that distinguishes them not only from fathers, but also from mothers of children without disabilities [Shearn, Todd 2000]. This identity comes with additional sanctions, and behavior that does not conform to gendered social norms can result in negative judgments. The same applies to gainful employment because gender issues seem to be relevant here as well. There is greater social acceptance of fathers taking up employment than mothers of children with disabilities. Lewis et al. [1999] also indicated that mothers who returned to paid work felt obliged to cite financial reasons rather than personal aspirations for returning to work and continuing their careers. Some mothers, even when their children reach adulthood, experience guilt and anxiety about leaving their disabled son or daughter in the care of others, including other family members.

Summing up, the results of this study suggest that one of the dominant experiences of being a parent of a child with a disability is a sense of being different. A child's intellectual disability means that the parent may have the sense of a pejorative difference; they may feel worse than the parents of healthy children. For parents of a person with a disability, the awareness of "otherness" creates a potential situation of identity devaluation and the formation of a negative identity. This feeling of otherness may accompany them for the rest of their lives. At the outset, its framework is determined by the birth of a "dysfunctional" child. Gradually, they are labelled "a parent of a disabled child", which is usually based on social stereotypes, sometimes prejudices, and a lack of understanding of their situation by others. This happens because the "otherness" is often synonymous with strangeness, and experiencing the otherness of others and their own otherness is one of the most difficult emotional and social experiences. Visible disability features stress as its foreground character in the social perception, changing the expectations, responses, ways of communication, or the readiness to enter into individual relationships.

At the same time, the lack of prospects for a change in the situation only increases the frustration and disappointment for these parents. It is further exacerbated by their belief about the social demands and expectations of both themselves and their offspring. Parents see their child through the prism of social opinion, where one of the most significant values in life is one's own child. You must love it, take care of it, and do everything to provide your child with the best development possible. When a child is intellectually disabled, parents must continuously struggle with negative evaluations that society ascribes to those children [cf. Zakrzewska-Manterys 2010]. 
At the same time, however, the instability and uncertainty of everyday life makes the achieved state highly unstable and often associated with high psychoemotional costs, despite a kind of balance being achieved. These costs seem to increase as the child grows up, often accompanied by the increasing visibility of the child's dysfunction.

\section{BIBLIOGRAPHY}

Barnes Colin, Geoff Mercer. 1997. Doing disability research. Leeds: The Disability Press.

Beresford Bryony, Parvaneh Rabiee, Patricia Sloper. 2007. Outcomes for parents with disabled children. Research Works 2007-03, Social Policy Research Unit. York: University of York.

Bosteels Sigrid, Geert van Hove, Michel Vandenbroeck. 2012. "The rollercoaster of experiences: Becoming the parent of a deaf child". Disability \& Society 27 (7): 983-996.

Burke Peter J. 2003. Relationships among multiple identities. In: Advances in identity theory \& esearch. P.J. Burke, T.J. Owens, R.T. Serpe, P.A. Thoits (eds.), 195-214. New York: Kluwer Academic/Plenum.

Charmaz Kathy. 2006. Constructing grounded theory. A practical guide through qualitative analysis. Thousand Oaks, CA: Sage Publications.

Cronin Mary. 2018. "'Special mothers' in Ireland: Gender, identity and the social construction of caring for a relative with an intellectual disability". International Journal of Care and Caring 2(4): $575-580$.

Glaser Barney G. 1978. Theoretical sensitivity. Advances in the methodology of grounded theory. Mill Valley, CA: The Sociology Press.

Glaser Barney G., Anselm L. Strauss. 1967. The discovery of grounded theory. Strategies for qualitative research. Chicago: Aldine.

Gray David E. 2002. “«Everybody just freezes. Everybody is just embarrassed»: Felt and enacted sigma among parents of children with high functioning autism». Sociology of Health and Illness 24 (6): 734-749.

Hodapp Robert M. 2007. "Families of persons with Down syndrome: New perspectives, findings, and research and service needs". Mental Retardation and Developmental Disabilities Research Reviews 13(3): 279-287.

Hodapp Robert M., Laraine M. Glidden, Ann P. Kaiser. 2005. "Siblings of persons with disabilities: Toward a research agenda". Mental Retardation 43 (5): 334-338.

Holland Kate R., Warwick Blood. 2008. Carers'perspectives on caring: A qualitative analysis of open-ended eesponses to the Carer Health and Wellbeing Index Survey 2007. Deakin, ACT: Carers Australia.

Hughes Nic, Louise Locock, Sue Ziebland. 2013. "Personal identity and the role of «carer» among relatives and friends of people with multiple sclerosis". Social Science and Medicine 96: 78-85.

Konieczna Agnieszka. 2012. Dążenia rodziców do aktywizacji zawodowej dzieci z niepełnosprawnością - lęk o przyszłość. In: Aktywność zawodowa osób z niepetnosprawnościq. D. Tomczyszyn, W. Romanowicz (eds.), 277-279. Biała Podlaska: Wyd. PSW.

Kościelska Małgorzata. 1995. Oblicza upośledzenia. Warszawa: PWN. 
Lewis Suzan, Carolyn Kagan, Patricia Heaton, Maureen Cranshaw. 1999. "Economic and psychological benefits from employment: The experiences and perspectives of mothers of disabled children". Disability and Society 14(4): 561-575.

Miles Matthew B., Michael Huberman, Johnny Saldana. 2014. Qualitative data analysis: A method sourcebook. Sage Publications.

Niedbalski Jakub. 2019. „Realizowanie ról rodzicielskich i konstruowanie tożsamości rodziców dziecka z niepełnosprawnością intelektualną”. Studia Socjologiczne 234(3): 135-170.

Niedbalski Jakub, Izabela Ślęzak. 2012. „Analiza danych jakościowych przy użyciu programu NVivo a zastosowanie procedur metodologii teorii ugruntowanej”. Przegląd Socjologii Jakościowej 8(1): 126-165.

O'Connor Deborah. 2007. "Self-identifying as a caregiver: Exploring the positioning process". Journal of Aging Studies 21: 165-174.

Orsmond Gael I., Marsha M. Seltzer, Marty Krauss, Jinkuk W. Hong. 2003. "Behavior problems in adults with mental retardation and maternal well-being: Examination of the direction of effects". American Journal on Mental Retardation 108 (4):257-271.

Pavia Teresa M., Marlys J. Mason. 2004. "The reflexive relationship between consumer behavior and adaptive coping". Journal of Consumer Research 31(2): 441-54.

Phyllis Solomon, Jeffrey Draine.1995. "Subjective burden among family members of mentally ill adults: Relation to stress, coping and adoption". American Journal of Orthopsychiatry 65(3): 419-427.

Riemann Gerhard, Fritz Schütze. 1992. „«Trajektoria» jako podstawowa koncepcja teoretyczna w analizach cierpienia i bezładnych procesów społecznych". Kultura i Społeczeństwo 36(2): 89-110.

Rix Jonathan, Alice Paige-Smith. 2008. “«A different head?» Parental agency and early intervention". Disability \& Society 23(3): 211-221.

Ryan Sara, Katherine Runswick-Cole. 2008. "Repositioning mothers: Mothers, disabled children and disability studies". Disability and Society 23(3): 199-201.

Sałkowska Marta. 2015. Matka Downa. Piętno - znaczenia - strategie. Kraków: Zakład Wydawniczy "NOMOS".

Schütze Fritze. 1997. „Trajektoria cierpienia jako przedmiot badań socjologii interpretatywnej”. Studia Socjologiczne 1: 11-56.

Shearn Julia, Stuart Todd. 2000. "Maternal employment and family responsibilities: The perspective of mothers of children with intellectual disabilities". Journal of Applied Research in Intellectual Disabilities 13(3): 109-31.

Singh Shailen. 2019. "I am who I need to be: Reflections on parental identity development from a father of a child with disabilities". Disability \& Society 34(5): 837-841.

Stengler-Wenzke Katarina, Johanna Trosbach, Sandra Dietrich, Matthias C. Angermeyer. 2004. "Experience of stigmatization by relatives of patients with obsessive compulsive disorder". Archives of Psychiatric Nursing 18(3): 88-96.

Strauss Anselm L., Juliet Corbin. 1990. Basics of qualitative research: Techniques and procedures for developing grounded theory. Thousand Oaks (CA): Sage.

Todd Stuart, Julia Shearn. 1996a. "Struggles with time: The careers of Parents with adult sons and daughters with learning disabilities". Disability \& Society 11(3): 379-402.

Todd Stuart, Julia Shearn. 1996b. "Time and the person: The impact of support services on the lives of parents of adults with intellectual disabilities". Journal of Applied Research in Intellectual Disabilities 9: 40-60. 
Tomczyszyn Dorota. 2015. Rola matki i ojca $w$ rodzinie z dzieckiem z niepetnosprawnościa intelektualną. Biała Podlaska: Wydawnictwo PSW JPII

Walden Sarah, Nancy Pistrang, Theresa Joyce. 2000. "Parents of adults with intellectual disabilities: Quality of life and experiences of caring". Journal of Applied Research in Intellectual Disabilities 13: 62-76.

Ytterhus Borgunn, Christian Wendelborg, Hege Lundeby. 2008. "Managing turning points and transitions in childhood and parenthood: Insights from families with disabled children in Norway". Disability \& Society 23(6): 625-636.

Zakrzewska-Manterys Elżbieta. 2010. Upośledzeni umysłowo. Poza granicami człowieczeństwa. Warszawa: Wydawnictwo Uniwersytetu Warszawskiego.

Jakub Niedbalski

\section{POMIĘDZY (SAMO)WYKLUCZENIEM A SPOLECZNĄ INTEGRACJĄ - ANALIZA PROCESU REKONSTRUOWANIA TOŻSAMOŚCI RODZICÓW NA PRZESTRZENI CYKLÓW ŻYCIA DZIECKA Z NIEPEŁNOSPRAWNOŚCIĄ INTELEKTUALNĄ}

Streszczenie

Artykuł poświęcony jest problematyce tworzenia i artykułowania tożsamości rodziców dzieci z niepełnosprawnością intelektualną. W niniejszej pracy dąży się do zdekonstruowania procesu rekonstrukcji tożsamości rodziców dzieci z niepełnosprawnością intelektualną oraz poznania sposobów, w jakie rodzice dzieci z niepełnosprawnością postrzegają otaczający ich świat, usensowniając w określony sposób pewne jego elementy, co z kolei stanowi podstawę do podjęcia przez nich działań, poprzez które kształtować będą przestrzeń swojego życia. W związku z tym, by osadzić analizę, jaką przedstawia niniejsze opracowanie, w szerszej perspektywie teoretycznej odwołano się do kluczowych założeń studiów nad życiem społecznym, jakie wyłaniają się z koncepcji symbolicznego interakcjonizmu. Jako materiał badawczy posłużyły wywiady nieustrukturyzowane na temat osobistych doświadczeń rodziców, natomiast analizę danych poprowadzono zgodnie z zasadami metodologii ugruntowanej.

Słowa kluczowe: niepełnosprawność, rodzina, dziecko, tożsamość, badania jakościowe 